\title{
Pneumatosis Cystoides Intestinalis Secondary to Sunitinib Treatment for Gastrointestinal Stromal Tumor
}

\author{
Yoh Asahi $^{\mathrm{a}}$ Takuto Suzuki $^{\mathrm{a}} \quad$ Akiufumi Sawada $^{\mathrm{a}}$ Masaya Kina $^{\mathrm{a}}$ \\ Joji Takada ${ }^{a}$ Hiroko Gotodab Hiroyuki Masuko ${ }^{a}$ \\ aDepartment of Gastroenterological Surgery, Nikko Memorial Hospital, Muroran, Japan; \\ ${ }^{b}$ Department of Clinical Pathology, Nikko Memorial Hospital, Muroran, Japan
}

\section{Keywords}

Pneumatosis cystoides intestinalis · Sunitinib · Gastrointestinal stromal tumor · Liver metastasis

\begin{abstract}
A 67-year-old man with liver and retroperitoneal metastases from a gastrointestinal stromal tumor arising in the jejunum had been administered oral sunitinib for 2 months. He presented to our department with right-sided lower abdominal pain. His general condition was good, with no high-grade fever, and the other vital signs were also stable. Contrast-enhanced computed tomography was promptly performed, and pneumatosis cystoides intestinalis $(\mathrm{PCl})$ was detected in a wide area around the ileocecal lesion. There were no signs of acute abdomen requiring emergency surgery due to conditions such as intestinal perforation, ischemia, or obstruction. Sunitinib was discontinued and the patient was placed on nil orally with intravenous infusion. $\mathrm{PCl}$ resolved promptly and the patient was discharged on the 21st day after admission. $\mathrm{PCl}$ is a rare side effect of sunitinib with only 8 cases reported previously, which can complicate with acute abdomen or gastrointestinal perforation, in some cases. Thus, the early identification of sunitinib as the cause of $\mathrm{PCl}$ is important. Although $\mathrm{PCl}$ is a rare adverse effect of sunitinib, clinicians must be aware of it to promptly provide the correct diagnosis and treatment.




\section{Case Reports in Gastroenterology}

Case Rep Gastroenterol 2018;12:432-438

DOI: $10.1159 / 000490657$

(c) 2018 The Author(s). Published by S. Karger AG, Basel www.karger.com/crg

Asahi et al.: Pneumatosis Cystoides Intestinalis Secondary to Sunitinib Treatment for Gastrointestinal Stromal Tumor

\section{Background}

Progress in research on the mechanisms of tumorigenesis has led to development of new drugs for malignant neoplasms. Molecular-targeting agents are a new category of drugs that have been widely adopted for clinical use. Because of the unique actions of molecular-targeting agents, clinicians treating cancer should be aware of unexpected adverse effects that may be caused by these drugs. Sunitinib malate (Sutent ${ }^{\circledR}$; Pfizer, New York, NY, USA) is one of the molecular-targeting agents and is a tyrosine kinase inhibitor [1] used for the treatment of advanced gastrointestinal stromal tumor (GIST) and renal cell cancer. Pneumatosis cystoides intestinalis (PCI) is a rare adverse effect of sunitinib [2] and is characterized by the presence of gas in the submucosa or subserosa of the intestinal wall [3]. PCI also has other etiologies, including ischemia, inflammation, systemic disease, pulmonary disease, trauma/iatrogenic, other medications, and idiopathic [4]. Treatment of PCI is related to the underlying etiology and ranges from observation to surgical intervention.

We report a rare case of PCI caused by sunitinib therapy for GIST, which was successfully managed by conservative treatment without surgical intervention.

\section{Case Presentation}

A 67-year-old man was receiving treatment for recurrent GIST at our department. The patient had first undergone jejunal resection with peritoneal drainage for perforation of a jejunal tumor when he was 57 years old. The resected tumor was an irregular white mass lesion that measured $9.0 \times 3.5 \mathrm{~cm}$ and showed perforation. Pathological examination revealed interlacing bundles of spindle-shaped tumor cells with round nuclei (Fig. 1a). On immunostaining, the tumor cells were positive for c-KIT (Fig. 1b) and DOG-1 (Fig. 1c) and were focally positive for CD34 (Fig. 1d) and S-100 protein, but $\alpha$ SMA was negative. The MIB-I labeling index was low at $10 \%$. Based on these findings, the tumor was diagnosed as GIST arising in the jejunum. After the first operation, he underwent laparotomy twice more for resection of recurrent GIST and was placed on oral imatinib. After 5 years of imatinib treatment, liver metastasis (Fig. 2a) and retroperitoneal metastasis (Fig. 2b) were detected by contrast-enhanced computed tomography (CT). At that time, there was no sign of PCI on the CT scans (Fig. 2c). Imatinib was discontinued and oral administration of sunitinib was started with a regimen of $50 \mathrm{mg}$ daily for 4 weeks followed by 2 weeks off therapy. After 2 months of sunitinib administration, the patient presented to our department with pain in the lower right abdomen. His general condition was good, with no fever, and the other vital signs were also stable. The abdomen was soft and flat, although localized tenderness without rebound was detected in the lower right quadrant. The patient's medical history included hypertension and diabetes. Hematology tests were within the normal range $\left(\mathrm{WBC}\right.$ was $4,990 / \mu \mathrm{L}, \mathrm{Hb}$ was $13.9 \times 10^{4} / \mu \mathrm{L}$, and Plt was $13.9 \times$ $10^{4} / \mu \mathrm{L}$ ), but CRP was elevated to $5.18 \mathrm{mg} / \mathrm{dL}$. There was no evidence of kidney or liver dysfunction. Contrast-enhanced CT was performed, showing that the metastasis in the liver was unchanged and the retroperitoneal tumor was diminishing. However, CT scans also revealed PCI in a broad area around the ileocecal region (Fig. 3a). There was no free gas and no ascites. Administration of sunitinib was discontinued, and the patient was admitted to our department for observation. A proton pump inhibitor and a calcium channel blocker were continued 


\section{Case Reports in Gastroenterology}

Case Rep Gastroenterol 2018;12:432-438

DOI: $10.1159 / 000490657$

(c) 2018 The Author(s). Published by S. Karger AG, Base www.karger.com/crg

Asahi et al.: Pneumatosis Cystoides Intestinalis Secondary to Sunitinib Treatment for Gastrointestinal Stromal Tumor

and diabetic drugs (dipeptidyl peptidase-4 inhibitor, sulfonylurea, voglibose) were discontinued. He was placed on nil orally with intravenous infusion for 5 days. Diabetic drugs were restarted at the point of re-starting oral intake. The abdominal symptoms resolved, and PCI showed improvement when plain CT was performed on the 6th day after admission (Fig. 3b). There was no recurrence of abdominal symptoms, and plain CT on the 19th day after admission demonstrated complete resolution of PCI (Fig. 3c). Laboratory tests showed normalization of CRP. The patient was discharged on the 21st day after admission. Administration of sunitinib was not restarted. The patient subsequently underwent his 4 th abdominal operation, which was partial hepatectomy and resection of the retroperitoneal tumor. No signs of PCI were detected during surgery, as expected from the preoperative examinations, including CT.

\section{Discussion}

PCI is a rare adverse effect of sunitinib that is characterized by multiple gas-filled cysts within the submucosa or subserosa of the intestinal wall [5]. The etiology of PCI can be classified into four categories [6]: (A) changes of the intestinal wall, such as inflammatory bowel disease and mesenteric ischemia; (B) bowel distention, such as gastric and or intestinal dilatation due to spontaneous, traumatic, and iatrogenic causes; (C) peritonitis caused by diverticulitis, abdominal wall gangrene, or pylephlebitis; and (D) miscellaneous etiologies, such as transplantation, pneumatosis intestinalis, corticosteroid therapy, and chronic pulmonary disease.

Sunitinib (Sutent ${ }^{\circledR}$; Pfizer, New York, NY, USA) is a tyrosine kinase inhibitor that has been approved by the Food and Drug Administration for advanced GIST and renal cell cancer. It targets various receptors, including vascular endothelial growth factor (VEGF) receptors, platelet-derived growth factor (PDGF) receptors, and c-KIT [1]. In patients with refractory GIST treated by sunitinib, the median time to tumor progression improved to 27.3 weeks compared with 6 weeks for patients receiving placebo $(p<0.0001)$ [7]. Gastrointestinal adverse effects of sunitinib are not uncommon, with diarrhea being most frequent [7]. However, PCI is rarely reported as an adverse effect of sunitinib. Our search of the English and Japanese literature only identified 8 cases of PCI during sunitinib administration (Table 1) [2, 8-12]. The precise mechanism of PCI related to sunitinib therapy is unknown. Bevacizumab (another VEGF inhibitor) reduces the capillary density in the intestinal wall, leading to decreased mucosal regenerative capacity that may contribute to development of intestinal micro-perforations [13]. A report about PCI related to sunitinib by Flaig et al. [2] mentioned the pathological findings of the resected right colon, suggesting that ischemic colitis with chronic inflammation led to the occurrence of PCI.

$\mathrm{PCI}$ is usually diagnosed by CT, as in the present case. The other imaging examination that may be useful for diagnosis of PCI is a plain X-ray film of the abdomen. Treatment of PCI depends on its etiology and ranges from conservative management to surgery. Conservative management includes simple observation, hyperbaric oxygen therapy, parenteral nutrition, and administration of antibiotics. Surgery is needed when PCI is complicated by perforation, for the management of primary conditions like intestinal ischemia or obstruction, or when conservative therapy fails. Exclusion of conditions that need surgical treatment is important 
Asahi et al.: Pneumatosis Cystoides Intestinalis Secondary to Sunitinib Treatment for Gastrointestinal Stromal Tumor

to avoid unnecessary surgery. In the present case, there was no indication for surgery because there were no signs of intestinal perforation, ischemia, or obstruction. It has been suggested that the WBC is significantly correlated with ischemia complicating PCI [4]. The WBC was within the normal range in the present patient. Because more severe conditions such as perforation may be associated with PCI [10], prompt identification of sunitinib as the cause is important and clinicians must be aware of this rare adverse effect. When PCI is induced by a medication, discontinuation of the relevant drug should be considered $[2,9,11,12]$. Although sunitinib was effective for recurrent GIST in the present case, it was discontinued because of the risk of severe complications such as intestinal perforation [10]. After discontinuation of sunitinib, PCI recovered promptly in the present case and there was no recurrence. According to one case report, sunitinib was reintroduced after resolution of PCI and there was no recurrence [8]. We decided not to restart sunitinib in the present patient, considering the risk of recurrent PCI and its complications, as in other reports $[9,11,12]$.

In conclusion, we experienced a rare case of PCI related to sunitinib that was promptly diagnosed after the onset of abdominal symptoms. PCI resolved completely after discontinuation of sunitinib. Early diagnosis of PCI related to sunitinib is important, so clinicians should be aware of this rare adverse effect.

\section{Statement of Ethics}

Consent for publication has been obtained from the patient.

\section{Disclosure Statement}

The authors declare no conflicts of interest.

\section{References}

1 Atkins M, Jones CA, Kirkpatrick P. Sunitinib maleate. Nat Rev Drug Discov. 2006 Apr;5(4):279-80.

2 Flaig TW, Kim FJ, La Rosa FG, Breaker K, Schoen J, Russ PD. Colonic pneumatosis and intestinal perforations with sunitinib treatment for renal cell carcinoma. Invest New Drugs. 2009 Feb;27(1):83-7.

3 Pear BL. Pneumatosis intestinalis: a review. Radiology. 1998 Apr;207(1):13-9.

4 Treyaud MO, Duran R, Zins M, Knebel JF, Meuli RA, Schmidt S. Clinical significance of pneumatosis intestinalis - correlation of MDCT-findings with treatment and outcome. Eur Radiol. 2017 Jan;27(1):70-9.

5 Ivanović A, Kovač J, Mašulović D, Stefanović A, Jakšić E, Saranović D. Education and imaging. Gastrointestinal: the role of multidetector computer tomography in diagnosis of pneumatosis cystoides intestinalis. J Gastroenterol Hepatol. 2012 Jan;27(1):182.

6 Sebastià C, Quiroga S, Espin E, Boyé R, Alvarez-Castells A, Armengol M. Portomesenteric vein gas: pathologic mechanisms, CT findings, and prognosis. Radiographics. 2000 Sep-Oct;20(5):1213-26.

7 Goodman VL, Rock EP, Dagher R, Ramchandani RP, Abraham S, Gobburu JV, et al. Approval summary: sunitinib for the treatment of imatinib refractory or intolerant gastrointestinal stromal tumors and advanced renal cell carcinoma. Clin Cancer Res. 2007 Mar;13(5):1367-73.

8 Coriat R, Ropert S, Mir O, Billemont B, Chaussade S, Massault PP, et al. Pneumatosis intestinalis associated with treatment of cancer patients with the vascular growth factor receptor tyrosine kinase inhibitors sorafenib and sunitinib. Invest New Drugs. 2011 Oct;29(5):1090-3. 


\section{Case Reports in \\ Gastroenterology}

\begin{tabular}{l|l}
\hline Case Rep Gastroenterol 2018;12:432-438 \\
\hline DOI: 10.1159/000490657 & $\begin{array}{l}\text { @ 2018 The Author(s). Published by S. Karger AG, Basel } \\
\text { www.karger.com/crg }\end{array}$ \\
\hline
\end{tabular}

Asahi et al.: Pneumatosis Cystoides Intestinalis Secondary to Sunitinib Treatment for Gastrointestinal Stromal Tumor

9 Jarkowski A 3rd, Hare R, Francescutti V, Wilkinson N, Khushalani N. Case report of pneumatosis intestinalis secondary to sunitinib treatment for refractory gastrointestinal stromal tumor. Anticancer Res. 2011 Oct;31(10):3429-32.

10 Shinagare AB, Howard SA, Krajewski KM, Zukotynski KA, Jagannathan JP, Ramaiya NH. Pneumatosis intestinalis and bowel perforation associated with molecular targeted therapy: an emerging problem and the role of radiologists in its management. AJR Am J Roentgenol. 2012 Dec;199(6):1259-65.

11 Ohtake S, Namura K, Fujikawa A, Sawada T, Ohta J, Moriyama M, et al. [A case of pneumatosis cystoides intestinalis secondary to sunitinib treatment for renal cell carcinoma]. Hinyokika Kiyo. 2014 Feb;60(2):758.

12 Lee YS, Han JJ, Kim SY, Maeng CH. Pneumatosis cystoides intestinalis associated with sunitinib and a literature review. BMC Cancer. 2017 Nov;17(1):732.

13 Asmis TR, Chung KY, Teitcher JB, Kelsen DP, Shah MA. Pneumatosis intestinalis: a variant of bevacizumab related perforation possibly associated with chemotherapy related GI toxicity. Invest New Drugs. 2008 Feb;26(1):95-6.

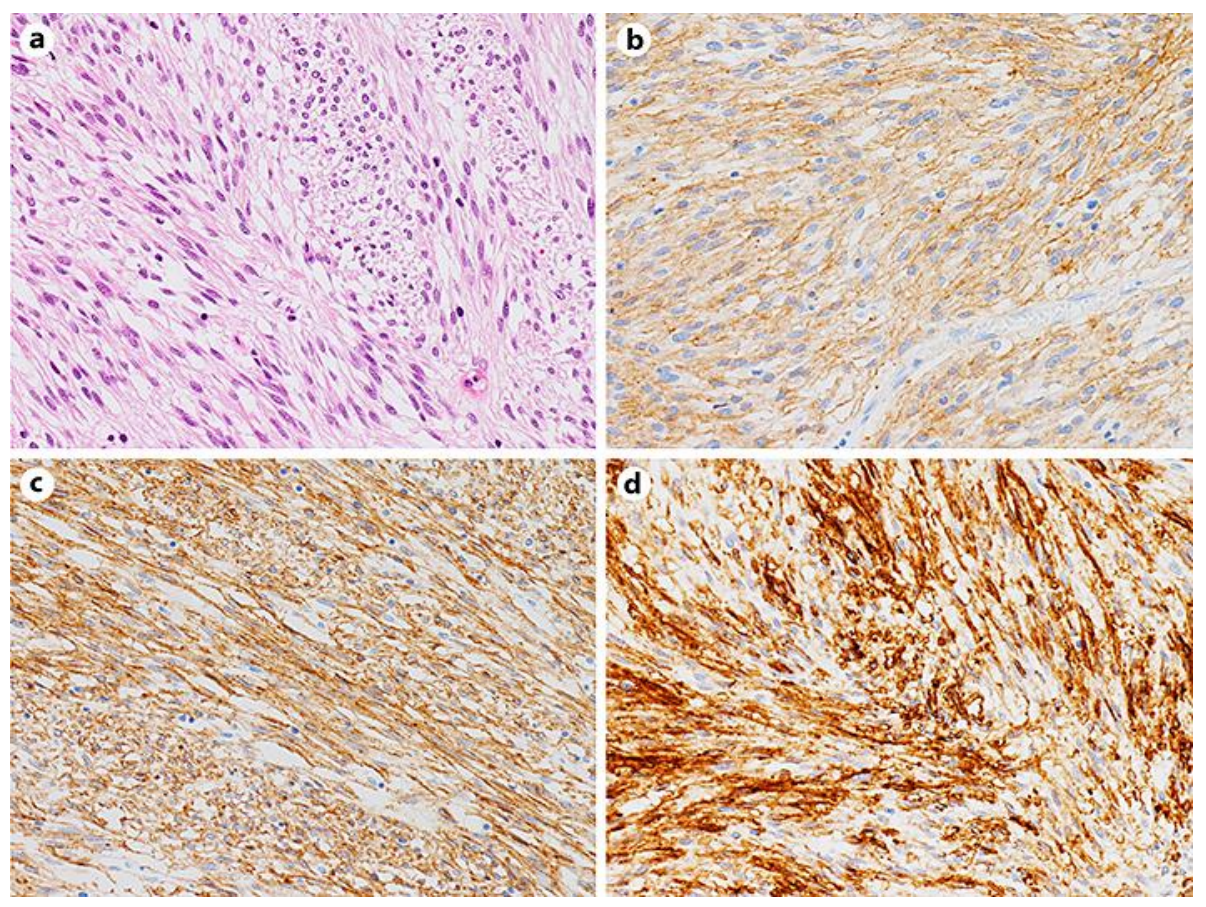

Fig. 1. Pathological examination of the GIST arising in the jejunum. a The tumor is mainly composed of spindle-shaped cells (HE stain, original magnification $\times 400$ ). b Immunostaining for c-KIT was positive in tumor cells (HE stain, original magnification $\times 400$ ). c Immunostaining for DOG-1 was positive in tumor cells (HE stain, original magnification $\times 400$ ). $\mathbf{d}$ Immunostaining for CD34 protein was weakly positive in tumor cells (HE stain, original magnification $\times 400$ ). 


\section{Case Reports in Gastroenterology}
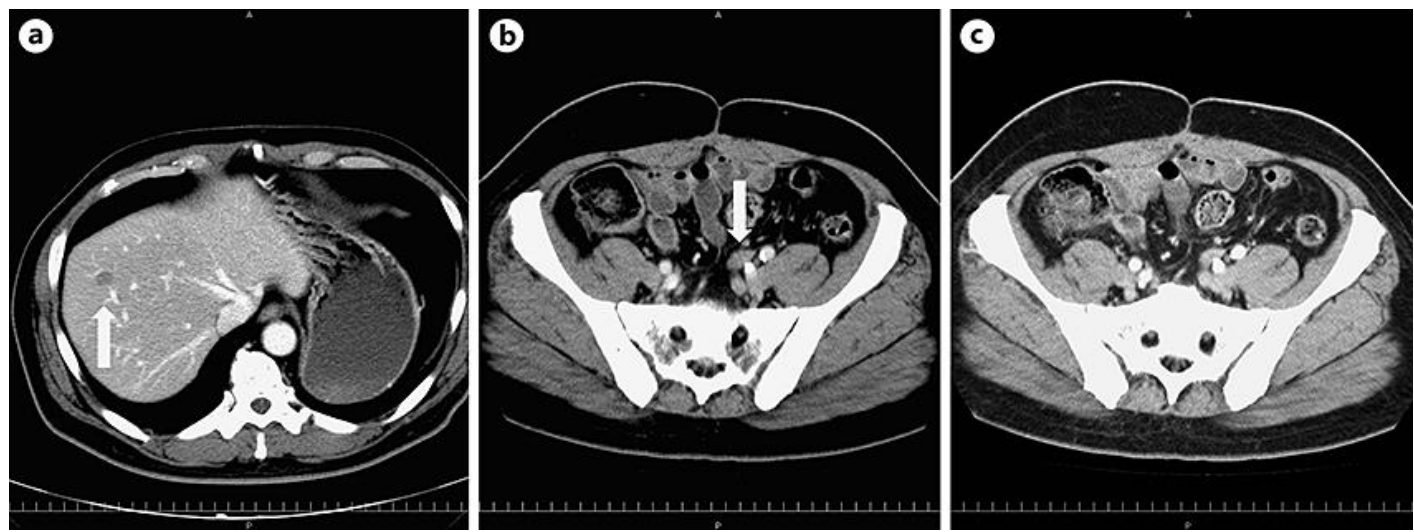

Fig. 2. CT before administration of sunitinib. a Liver metastasis (arrow). b Retroperitoneal metastasis (arrow). $\mathbf{c}$ There is no evidence of PCI.
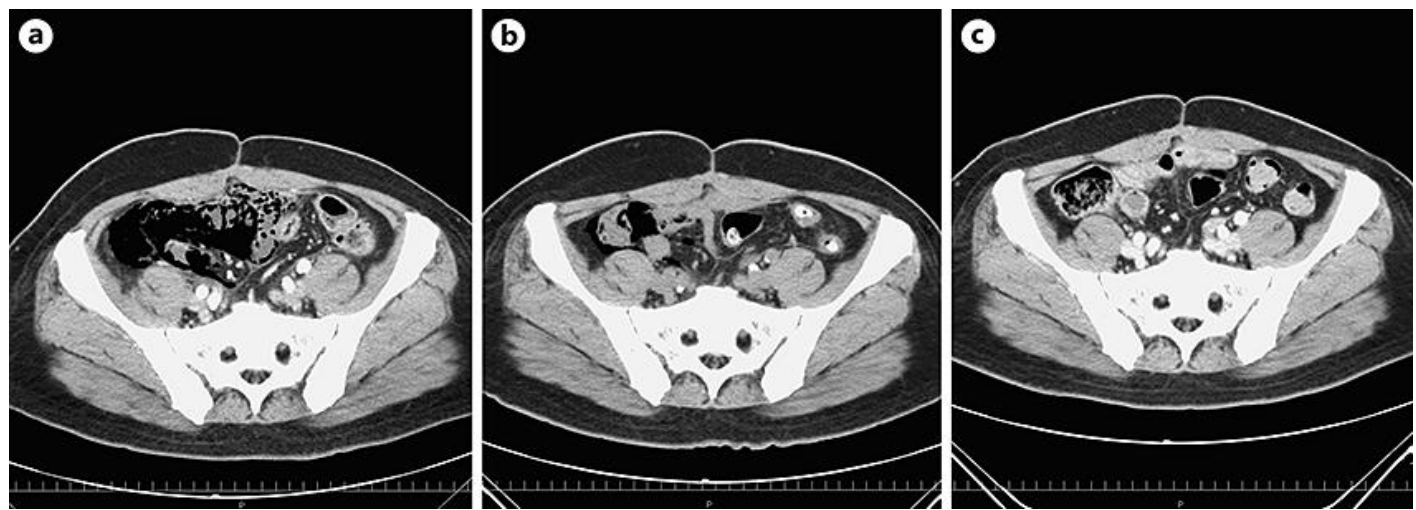

Fig. 3. CT performed at the time of PCI diagnosis and on follow-up. a CT performed for the detection of the cause of right lower abdominal pain. PCI is seen in a wide area around the ileocecal region. There is no free gas or ascites. b CT on the 6th day after discontinuation of sunitinib. PCI is reduced. c CT on the 19th day after discontinuation of sunitinib. PCI has completely disappeared. 


\section{Case Reports in Gastroenterology}

\begin{tabular}{l|l}
\hline Case Rep Gastroenterol 2018;12:432-438 \\
\hline DOI: 10.1159/000490657 & $\begin{array}{l}\text { (C) 2018 The Author(s). Published by S. Karger AG, Basel } \\
\text { www.karger.com/crg }\end{array}$ \\
\hline
\end{tabular}

Asahi et al.: Pneumatosis Cystoides Intestinalis Secondary to Sunitinib Treatment for Gastrointestinal Stromal Tumor

Table 1. Previously reported PCI due to sunitinib

\begin{tabular}{|c|c|c|c|c|c|c|c|c|c|c|c|c|c|}
\hline Ref. & Sex & $\begin{array}{l}\text { Age, } \\
\text { years }\end{array}$ & $\begin{array}{l}\text { Primary } \\
\text { tumor }\end{array}$ & $\begin{array}{l}\text { Metastatic } \\
\text { sites }\end{array}$ & Prior therapy & $\begin{array}{l}\text { Dose, } \\
\text { mg/ } \\
\text { day }\end{array}$ & $\begin{array}{l}\text { Sunitinib } \\
\text { duration }\end{array}$ & $\begin{array}{l}\text { Medical } \\
\text { history }\end{array}$ & Symptoms & Location & $\begin{array}{l}\text { Per- } \\
\text { fora- } \\
\text { tion }\end{array}$ & Treatment & $\begin{array}{l}\text { Sunitinib } \\
\text { continua- } \\
\text { tion }\end{array}$ \\
\hline 2 & $\mathrm{~F}$ & NA & RCC & lung & $\begin{array}{l}\text { nephrectomy, } \\
\text { sorafenib, } \\
\text { high-dose IL-2 }\end{array}$ & 50 & 13 months & $\begin{array}{l}\text { calculus in } \\
\text { kidney }\end{array}$ & $\begin{array}{l}\text { abdominal } \\
\text { pain, } \\
\text { no urine output }\end{array}$ & $\begin{array}{l}\text { right } \\
\text { colon } \\
t\end{array}$ & no & $\begin{array}{l}\text { right-sided } \\
\text { hemi-colec- } \\
\text { tomy }\end{array}$ & NA \\
\hline 2 & $\mathrm{~F}$ & NA & RCC & lung & $\begin{array}{l}\text { nephrectomy, } \\
\text { high-dose IL-2 }\end{array}$ & 37.5 & 5 months & NA & $\begin{array}{l}\text { abdominal } \\
\text { pain, } \\
\text { diarrhea, } \\
\text { decrease in } \\
\text { appetite }\end{array}$ & $\begin{array}{l}\text { right } \\
\text { colon }\end{array}$ & no & $\begin{array}{l}\text { conservative } \\
\text { treatment }\end{array}$ & NA \\
\hline 8 & M & 68 & RCC & $\begin{array}{l}\text { lymph nodes, } \\
\text { bone }\end{array}$ & $\begin{array}{l}\text { nephrectomy, } \\
\text { irradiation, } \\
\text { temserolimus }\end{array}$ & 37.5 & 27 months & $\begin{array}{l}\text { pulmonary } \\
\text { embolism }\end{array}$ & $\begin{array}{l}\text { cauda equina } \\
\text { syndrome }\end{array}$ & $\begin{array}{l}\text { small } \\
\text { bowel }\end{array}$ & no & $\begin{array}{l}\text { surgical explo- } \\
\text { ration }\end{array}$ & $\begin{array}{l}\text { re-intro- } \\
\text { duced }\end{array}$ \\
\hline 9 & M & 73 & GIST & NA & imatinib & 37.5 & 68 days & $\begin{array}{l}\text { renal trans- } \\
\text { plantation, } \\
\text { depression }\end{array}$ & $\begin{array}{l}\text { abdominal } \\
\text { pain, } \\
\text { abdominal } \\
\text { bloating }\end{array}$ & $\begin{array}{l}\text { right } \\
\text { and trans- } \\
\text { verse colon }\end{array}$ & no & $\begin{array}{l}\text { conservative } \\
\text { treatment }\end{array}$ & $\begin{array}{l}\text { discontin- } \\
\text { ued }\end{array}$ \\
\hline 10 & NA & NA & RCC & NA & NA & NA & 3 months & NA & none & $\begin{array}{l}\text { small } \\
\text { bowel }\end{array}$ & yes & NA & NA \\
\hline 10 & NA & NA & RCC & NA & NA & NA & 1 months & NA & $\begin{array}{l}\text { abdominal } \\
\text { pain, } \\
\text { abdominal } \\
\text { distention }\end{array}$ & $\begin{array}{l}\text { stomach, } \\
\text { small } \\
\text { bowel, } \\
\text { cecum, } \\
\text { ascending } \\
\text { colon }\end{array}$ & yes & NA & NA \\
\hline 11 & M & 78 & RCC & $\begin{array}{l}\text { lung, sub- } \\
\text { epidermal }\end{array}$ & $\begin{array}{l}\text { nephrectomy, } \\
\text { VATS }\end{array}$ & 25 & NA & $\begin{array}{l}\text { diabetes, } \\
\text { polymyalgia } \\
\text { rheumatica, } \\
\text { hypertension }\end{array}$ & none & $\begin{array}{l}\text { right } \\
\text { and trans- } \\
\text { verse colon }\end{array}$ & no & $\begin{array}{l}\text { conservative } \\
\text { treatment }\end{array}$ & $\begin{array}{l}\text { discontin- } \\
\text { ued }\end{array}$ \\
\hline 12 & $\mathrm{~F}$ & 68 & PNET & liver & $\begin{array}{l}\text { octreotide } \\
\text { analogue, } \\
\text { everolims }\end{array}$ & 25 & NA & NA & $\begin{array}{l}\text { diarrhea, } \\
\text { fatigue, } \\
\text { dyspepsia, } \\
\text { abdominal } \\
\text { discomfort }\end{array}$ & $\begin{array}{l}\text { distal } \\
\text { ileum and } \\
\text { colon }\end{array}$ & no & $\begin{array}{l}\text { conservative } \\
\text { treatment }\end{array}$ & $\begin{array}{l}\text { discontin- } \\
\text { ued }\end{array}$ \\
\hline $\begin{array}{l}\text { pres } \\
\text { ent } \\
\text { case }\end{array}$ & & 67 & GIST & $\begin{array}{l}\text { liver, retro- } \\
\text { peritoneum }\end{array}$ & $\begin{array}{l}\text { jejunal resection, } \\
\text { tumor resection, } \\
\text { imatinib }\end{array}$ & 37.5 & 2 months & $\begin{array}{l}\text { diabetes, } \\
\text { hypertension }\end{array}$ & $\begin{array}{l}\text { abdominal } \\
\text { pain }\end{array}$ & $\begin{array}{l}\text { distal } \\
\text { ileum and } \\
\text { right colon }\end{array}$ & no & $\begin{array}{l}\text { conservative } \\
\text { treatment }\end{array}$ & $\begin{array}{l}\text { discontin- } \\
\text { ued }\end{array}$ \\
\hline
\end{tabular}

IL-2, interleukin-2; NA, data not available; PNET, pancreatic neuroendocrine tumor; RCC, renal cell cancer; Ref., reference. 